\title{
Effects of ovarian steroids and epidermal growth factor (EGF) on expression and bioactivation of specific regulators of transcription and translation in oviductal tissue in pigs
}

\author{
K. Wollenhaupt ${ }^{1}$, W. Tomek ${ }^{1}$, K-P. Brüssow ${ }^{1}$, U. Tiemann ${ }^{1}$, \\ T. Viergutz ${ }^{1}$, F. Schneider ${ }^{1}$ and G. Nürnberg ${ }^{2}$ \\ ${ }^{1}$ Unit of Reproductive Biology and ${ }^{2}$ Unit of Genetics and Biometry, Research Institute for \\ Biology of Farm Animals, 18196 Dummerstorf, Germany
}

The epidermal growth factor receptor (EGF receptor) system is involved in regulation of proliferation and differentiation in oviductal and endometrial tissues. In this study the influence of ovarian steroids and EGF on the expression and activity of specific markers of transcription (mitogen-activated protein kinase; MAP ${ }^{42 k}$ ) and translation (a potential repressor of eukaryotic initiation factor $4 \mathrm{E}$; 4E-BP1) in pig oviducts was investigated. Furthermore, determination of the distribution of translationally active (polysomal) and repressed (free) mRNA, and cell cycle analysis were performed. Oviductal tissue collected at two points of the oestrous cycle (days 12 and 20) from gilts and tissues from ovariectomized gilts with or without steroid replacement treatment were analysed. The influence of EGF was detected by culture of oviductal explants. MAP42k activity was stimulated by oestrogen treatment, whereas progesterone treatment appeared to decrease its activity.
High oestrogen but not high progesterone concentrations resulted in reduced mobility of 4E-BP1 on polyacrylamide gels, indicating its inactivation. EGF and oestrogen treatment of oviductal explants further reduced the mobility of 4E-BP1 on polyacrylamide gels. High concentrations of oestrogen in the plasma promoted cell cycle activity. Progesterone treatment alone did not stimulate the rate of DNA synthesis. There were no significant differences in the distribution of free oviductal poly $\left(\mathrm{A}^{+}\right) \mathrm{mRNA}$, but the amount of polysomal mRNA was downregulated by oestrogen and progesterone. Increased oestrogen concentrations are involved in the regulation of MAP42k and 4E-BP1 activation in the oviductal tissue of pigs. The effect of oestrogen and EGF in reducing the mobility of 4E-BP1 on gels in oviductal explants indicates that EGF may mediate the effect of oestradiol in the oviducts.

\section{Introduction}

Oviductal and endometrial tissues proliferate and differentiate actively under the influence of the steroid hormones oestrogen and progesterone during the oestrous cycle (Marcus, 1974; Jansen, 1980). Although the mechanisms involved in these processes are poorly understood, there is evidence that growth factors may play a role in mediating the action of steroid hormones in reproductive tissues. One mechanism by which oestradiol and progesterone might exert their mitogenic effects on the oviduct and uterus is by stimulating the epidermal growth factor receptor (EGF receptor) system (Mukku and Stancel, 1985; Huet-Hudson et al., 1990; Chegini et al., 1992; Hammond et al., 1993; Watson et al., 1996; Wollenhaupt et al., 2001). This contention is supported by the results of Salvatori et al. (2000) demonstrating a dose-dependent activation of transcription of the EGF receptor gene by ligand-bound oestrogen receptor $\alpha$ in HeLa cells. In addition to EGF receptor (also called ErbB1), three other

Email: wollenhaupt@fbn-dummerstorf.de transmembrane proteins that belong to the same family, ErbB2, ErbB3 and ErbB4, may co-operate in the signal transduction by EGF receptor ligands. Many details are known about these signalling pathways in carcinoma cell lines. However, the molecular and biochemical mechanisms that control the EGF receptor system-mediated processes of proliferation and differentiation in oviductal cells undergoing continuous synchronized waves of oestrogen and progesterone flux remain to be determined.

Signal transduction studies on carcinoma cell lines indicate that the initial step after binding of EGF to the EGF receptor involves activation of the cytoplasm receptor tyrosine kinase domain and autophosphorylation of the receptor protein. The phosphorylated tyrosine residues on receptor proteins serve as docking sites for specific $\mathrm{SH}_{2}-$ domain-containing proteins, leading to phosphorylation of cellular substrates. Although a clear definition of physiologically significant substrates has been slow to develop, many of these substrates must be associated with the large network of protein serine and threonine kinases present in eukaryotic cells (Ahn et al., 1990).

Phosphorylation of the EGF receptor protein can result in 
activation of the Ras-Raf-mitogen-activated protein (MAP) kinase as a main signalling pathway, transcription factor activation and cell mitogenesis in human and mouse carcinoma cell lines (Ahn et al., 1990; Ballou et al., 1991; Brown et al., 1994; Swantek and Baserga, 1999). In proliferating $\mathrm{HaCaT}$ cells the activation of MAP kinase is completely dependent on EGF receptor kinase activity (Garach-Jehoshua et al., 1999) and there is evidence to suggest that activation of EGF receptor could also be involved in the regulation of cellular translational control. The increase in the translation of certain mRNAs is an important response to mitogenic stimulation. As well as the activation of the cap-binding protein (elF-4E; eukaryotic initiation factor $4 \mathrm{E}$ ), phosphorylation of a specific repressor protein (4E-BP1; eukaryotic initiation factor 4E binding protein 1) can control cap-dependent translation of mRNAs with extensive secondary structures. Growth stimuli such as EGF, platelet-derived growth factor (PDGF) or insulin activate phosphorylation of 4E-BP1 (von Manteuffel et al., 1996), which decreases its affinity for elF-4E and releases the block on cap-dependent translation (Brown et al., 1994). These reactions are thought to result in facilitation of the attachment of smaller ribosomal subunits to mRNA.

The aim of the present study was to determine whether altered plasma steroid hormone concentrations during the oestrous cycle and after steroid replacement therapy influence the abundance and bioactivity of EGF-regulated specific markers of transcription and translation, such as MAP ${ }^{42 k}$ and $4 \mathrm{E}-\mathrm{BP} 1$, and the distribution of polysomal and free mRNA in pig oviducts. A secondary aim was to characterize the direct involvement of EGF in the expression and bioactivation of these factors.

\section{Materials and Methods}

\section{Materials}

Mouse EGF was purchased from Boehringer (Mannheim). $\gamma^{32}$ P-labelled ATP (specific activity $6000 \mathrm{Ci}$ $\mathrm{mmol}^{-1}$ ), $\left[2,4,6,7-{ }^{3} \mathrm{H}\right]$-oestradiol (specific activity $81 \mathrm{Ci}$ $\left.\mathrm{mmol}^{-1}\right), \quad\left[1,2,6,7-{ }^{3} \mathrm{H}\right]$-progesterone (specific activity $92 \mathrm{Ci} \mathrm{mmol}^{-1}$ ), anti-rabbit POD-linked antibody, enhanced chemiluminescence $(\mathrm{ECL})$ detection system and X-ray films were obtained from Amersham Pharmacia Biotech (Freiburg). Rabbit polyclonal antibodies to MAP42k and 4EBP1, mouse monoclonal antibodies to activated MAP kinase and protein A/G PLUS agarose were purchased from Santa Cruz (Heidelberg). [5,6- $\left.{ }^{3} \mathrm{H}\right]$-polyuridylic acid was purchased from NEN Life Science Products (Köln). Oestradiol benzoate was obtained from Jenapharm (Jena). Anti-mouse POD-linked antibody, myelin basic protein (MBP; from bovine brain), inhibitor peptide of cAMPdependent protein kinase (PKI) and all other reagents were acquired from Sigma (Deisenhofen). Regumate ${ }^{\circledR}$ was obtained from Serum-Werk (Bernburg), Pregmagon ${ }^{\circledR}$ was obtained from Impfstoffwerk (Dessau) and progesterone and Choriolutin ${ }^{\circledR}$ were obtained from Albrecht (Aulendorf).
Animals, preparation of oviductal tissue and recovery of blood samples

Mature crossbred Landrace gilts $(n=22)$, aged approximately 8.5 months, were used. Oestrus was synchronized by a daily feeding of $16 \mathrm{mg}$ altrenogest (Regumate ${ }^{\circledR}$ ) for a 15 day period and an application of 1000 iu PMSG (Pregmagon ${ }^{\circledR}$ ) at $24 \mathrm{~h}$ after the last administration of Regumate ${ }^{\circledR}$. Ovulation was induced by an application of 500 iu hCG (Choriolutin ${ }^{\circledR}$ ) at $80 \mathrm{~h}$ after the PMSG injection. The experimental design is shown (Table 1). Fourteen gilts were ovariectomized (OVX) on day 10 of the oestrous cycle (corresponding to day 11 after hCG administration). Four gilts received an injection of $500 \mu \mathrm{g}$ oestradiol benzoate-in-oil once a day on days 6-9 after ovariectomy (OVX + oestradiol benzoate group). Three pigs were injected with $100 \mathrm{mg}$ progesterone once a day on days 6-9 (OVX + progesterone) and three further animals were treated with $100 \mathrm{mg}$ progesterone from day 1 to day 5 and with $500 \mu \mathrm{g}$ oestradiol benzoate once a day on days 6-9 after ovariectomy (OVX + progesterone + oestradiol benzoate). Gilts were hysterectomized on day 10 after ovariectomy or additionally, on day $12(n=3)$ and day 20 $(n=5)$ of the oestrous cycle. The cyclic pigs were used to determine the influence of physiologically low and high plasma oestradiol and progesterone concentrations on the expression and bioactivation of specific markers of translation and transcription in the oviductal tissue. These investigations allowed assessment of the data of steroid replacement experiments under in vivo conditions. The reproductive tracts were brought to the laboratory within 10 min of hysterectomy. Oviductal samples were isolated and stored at $-80^{\circ} \mathrm{C}$. All pigs were fitted with an indwelling jugular catheter under ketamine-xylazine anaesthesia. Blood samples were collected twice a day $(08: 00 \mathrm{~h}$ and 14:00 h) from day 1 to day 9 after ovariectomy or from day 11 to day 19 of the oestrous cycle. Plasma was stored at $-20^{\circ} \mathrm{C}$ until analysis for progesterone and oestradiol was performed by radioimmunoassay.

\section{Radioimmunoassay}

Oestradiol. Estimation of oestradiol concentration was performed by a ${ }^{3} \mathrm{H}$-radioimmunoassay after extraction by diethylether. Recovery of added oestradiol in three different concentrations of diethylether was between $86 \%$ and $108 \%$ (mean 94.3\%). Assay data were not corrected for the oestradiol lost during extraction. Assays were done using $\left[2,4,6,7_{-}{ }^{3} \mathrm{H}\right]$-oestradiol as tracer, pure oestradiol as hormone standard and an antibody raised in rabbits against an oestradiol-6-CMO-BSA conjugate (Blödow et al., 1988). This antibody was purified by HPLC and used at a titre of 1:55 000. The bound:free separation was performed via the dextran-charcoal method. Radioactive counts were measured using a liquid scintillation counter with an integrated radioimmunoassay program (Rackbeta 1219; Wallac). The shape of the standard curve was not affected by addition of $\leqslant 1 \mathrm{ml}$ pig plasma with a low oestradiol 
Table 1. Experimental design

\begin{tabular}{|c|c|c|c|c|c|}
\hline Treatment group & $\begin{array}{c}\text { Day } 10 \text { of } \\
\text { oestrous cycle }\end{array}$ & $\begin{array}{l}\text { Days } 1-9 \text { after } \\
\text { ovariectomy }\end{array}$ & $\begin{array}{l}\text { Days } 1-5 \text { after } \\
\text { ovariectomy }\end{array}$ & $\begin{array}{c}\text { Days 6-9 after } \\
\text { ovariectomy }\end{array}$ & $\begin{array}{l}\text { Day } 10 \text { after } \\
\text { ovariectomy }\end{array}$ \\
\hline \multirow{5}{*}{$\begin{array}{l}\text { OVX }(n=4) \\
\text { OVX + oestradiol } \\
\text { benozate }(n=4) \\
\text { OVX + progesterone } \\
(n=3) \\
\text { OVX + progesterone } \\
+ \text { oestradiol benzoate } \\
(n=3)\end{array}$} & Ovariectomy & Blood collection & - & Vehicle & Hysterectomy \\
\hline & Ovariectomy & Blood collection & - & $500 \mu \mathrm{g}$ oestradiol & Hysterectomy \\
\hline & Ovariectomy & Blood collection & - & $\begin{array}{l}\text { benzoate } \\
100 \text { mg progesterone }\end{array}$ & Hysterectomy \\
\hline & Ovariectomy & Blood collection & $\begin{array}{l}100 \mathrm{mg} \\
\text { progesterone }\end{array}$ & $\begin{array}{l}500 \mu \text { g oestradiol } \\
\text { benzoate }\end{array}$ & Hysterectomy \\
\hline & & $\begin{array}{l}\text { Days } 11-19 \text { of } \\
\text { oestrous cycle }\end{array}$ & $\begin{array}{l}\text { Day } 12 \text { of } \\
\text { oestrous cycle }\end{array}$ & & $\begin{array}{l}\text { Day } 20 \text { of } \\
\text { oestrous cycle }\end{array}$ \\
\hline Day $12(n=3)$ & & - & Hysterectomy & & - \\
\hline Day $20(n=5)$ & & Blood collection & - & & Hysterectomy \\
\hline
\end{tabular}

OVX: ovariectomized.

concentration treated with dextran-charcoal. The standard curve ran parallel to that obtained for a pig plasma dilution series. At a 95\% confidence interval, 3 pg oestradiol $\mathrm{ml}^{-1}$ plasma was significantly different from the zero standard $(P<0.05)$. Intra- and interassay coefficients of variation were 6.2 and $9.1 \%$, respectively.

Progesterone. Analysis of progesterone was performed in each $50 \mu \mathrm{l}$ plasma sample using a direct ${ }^{3} \mathrm{H}$-radioimmunoassay with $\left[1,2,6,7-{ }^{3} \mathrm{H}\right]$-progesterone as tracer, pure progesterone as hormone standard and a rabbit antibody raised against progesterone-11-hemisuccinateBSA purified by HPLC (titre 1:200000). Incubations, bound:free separation and counting were performed as described for oestradiol. The sensitivity of the method was $20 \mathrm{pg} \mathrm{ml}^{-1}$ plasma. The coefficients of variation were $7.6 \%$ (intra-assay) and $9.8 \%$ (interassay).

\section{Preparation of tissue extracts}

For the immunoblot analysis of the MAP ${ }^{42 k}$ and 4E-BP1, the entire oviduct (including ampulla and isthmus) was homogenized in $4 \mathrm{ml}$ of $20 \mathrm{mmol}$ Hepes $\mathrm{I}^{-1}, 1 \mathrm{mmol}$ EGTA

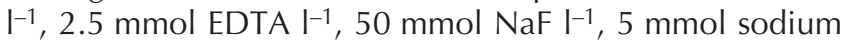
pyrophosphate $\mathrm{I}^{-1}, 5 \mathrm{mmol} \beta$-glycerophosphate $\mathrm{I}^{-1}, 2 \mathrm{mmol}$ dithiothreitol I-1, $1 \mathrm{mmol} \mathrm{Na}_{3} \vee_{4} \mathrm{I}^{-1}, 0.1 \%$ (v/v) NP40,

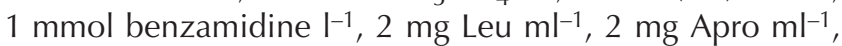
$\mathrm{pH} 7.4$ using three bursts of $15 \mathrm{~s}$ duration in an Ultra-Turrax (IKA, Staufen). The crude homogenate was filtered through four layers of gauze. Filtrates were centrifuged at $800 \mathbf{g}$ for $10 \mathrm{~min}$ at $4^{\circ} \mathrm{C}$ and the supernatants were collected and centrifuged at $105000 \mathrm{~g}$ for $1 \mathrm{~h}$. Resulting supernatants were used for 4E-BP1 and MAP42k immunoblot analysis. Protein concentration was determined as described by Lowry et al. (1951) using BSA as a standard.

\section{Immunoblot analysis}

Equal amounts of oviductal protein $(30 \mu \mathrm{g})$ were subjected to $9 \%((\mathrm{w} / \mathrm{v})$ acrylamide:bisacrylamide 100:1, for $\mathrm{MAP}^{42 \mathrm{k}}$ ) or $15 \%(\mathrm{w} / \mathrm{v})$ polyacrylamide gel electrophoresis (for 4E-BP1), under reducing conditions. The electrotransfer of proteins to nitrocellulose membranes (Schleicher and Schuell, Dassel) was performed for $1 \mathrm{~h}$ at $1 \mathrm{~mA} \mathrm{~cm}{ }^{-2}$, followed by blocking in TBST $\left(20 \mathrm{mmol}^{\text {Tris }} \mathrm{I}^{-1}, 500 \mathrm{mmol}\right.$ $\mathrm{NaCl} \mathrm{I}^{-1}$, pH 7.5, 0.1\% (v/v) Tween 20), supplemented with $5 \%(\mathrm{v} / \mathrm{v})$ horse serum overnight at $4{ }^{\circ} \mathrm{C}$. The membranes were probed in different experiments with a primary antibody to MAP42k (1:1000), activated MAP kinase (antibody is reactive with Tyr-phosphorylated MAP42k and MAP44k; 1:500) or 4E-BP1 (1:1000) in TBST supplemented with $2.5 \%$ horse serum for $3 \mathrm{~h}$ at $20^{\circ} \mathrm{C}$, washed twice in TBST and TBST supplemented with $0.5 \%$ horse serum, and incubated with donkey anti-rabbit antibody (1:10000 dilution, for MAP42k and 4E-BP1) or anti-mouse IgG for activated MAP kinase $(1: 4000)$ conjugated with horseradish peroxidase for $1.5 \mathrm{~h}$ at $20^{\circ} \mathrm{C}$. After washing with TBST, blots were developed using the ECL detection system according to the manufacturer's protocol.

\section{Measurement of $M A P^{42 k}$}

The activity of MAP42k was measured by an immune complex kinase assay. In brief, aliquots of supernatants containing $100 \mu \mathrm{g}$ total protein were incubated overnight at $4^{\circ} \mathrm{C}$ with $5 \mu \mathrm{l}$ anti-MAP ${ }^{42 \mathrm{k}}$ antibody and $15 \mu \mathrm{l}$ protein A/G Plus agarose in homogenization buffer (total volume $200 \mu \mathrm{l})$. The immune complexes were collected by centrifugation at $550 \mathrm{~g}$ for $10 \mathrm{~min}$, washed three times with kinase assay buffer $\left(20 \mathrm{mmol}\right.$ Hepes $\mathrm{I}^{-1}, 10 \mathrm{mmol} \mathrm{MgCl}_{2} \mathrm{I}^{-1}$, $1 \mathrm{mmol}$ dithiothreitol $\mathrm{I}^{-1}, 100 \mu \mathrm{mol} \mathrm{Na}_{2} \mathrm{VO}_{4} \mathrm{I}^{-1}, \mathrm{pH}$ 7.5) 
(a)

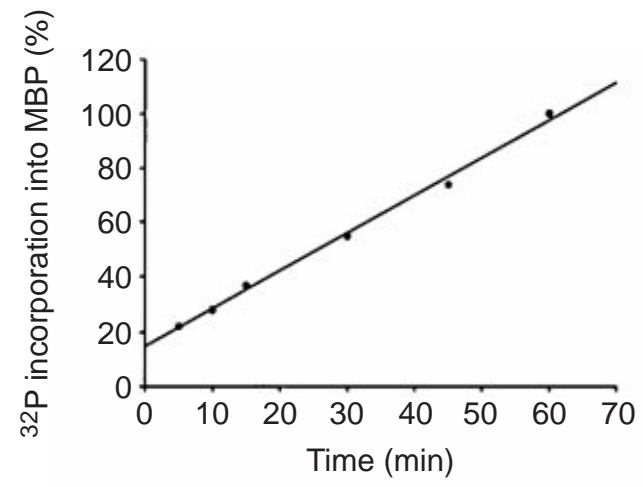

(b)
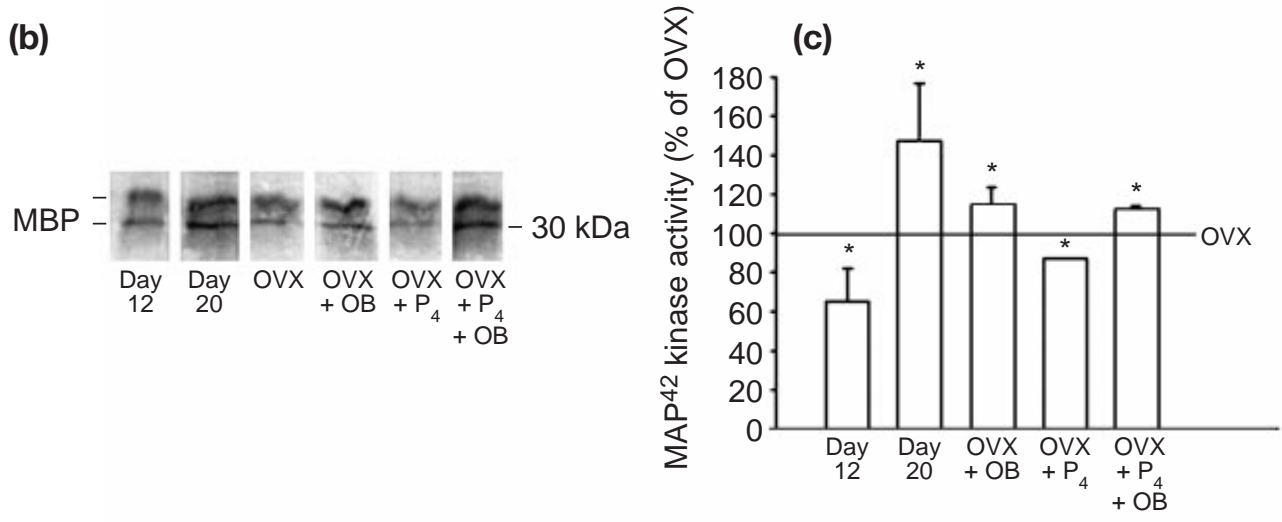

(d)

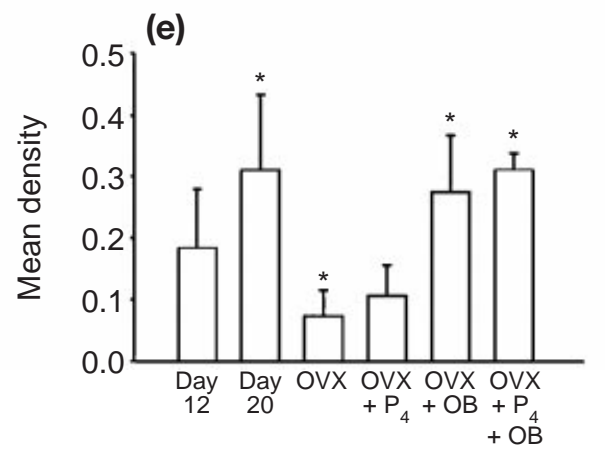

Fig. 1. (a) Time course of myelin basic protein (MBP) phosphorylation by mitogen-activated protein kinase $\left(\mathrm{MAP}^{42 \mathrm{k}}\right)$ in oviductal tissue of cyclic pigs on day 20 of the oestrous cycle. Percentage increase of incorporated radioactivity into MBP results in a linear relationship, with correlation coefficient $r=0.99$. (b) Representative autoradiograph of MBP phosphorylation by MAP ${ }^{42 k}$ as evaluated in (c). (c) MAP ${ }^{42 k}$ activity in the tissues of cyclic and steroid-treated pigs. A 100\% kinase activity refers to values obtained from tissue of ovariectomized (OVX) pigs. *Relative activity is significantly different from that of ovariectomized tissue $(P<0.05)$. (d) Immunoblot analysis of activated MAP kinase in oviductal tissue of cyclic and steroid-treated gilts as evaluated in (e). (e) Densitometric analysis of immune signals of activated MAP kinase. *Band density is significantly different from that of ovariectomized tissue $(P<0.05)$. The experiments were done with different animals: $n=2$ for day 12 pigs; $n=5$ for day 20 pigs; $n=4$ for ovariectomized (OVX) pigs; $n=$ 4 for OVX + oestradiol benzoate (OB)-treated pigs; $n=3$ for OVX + progesterone $\left(\mathrm{P}_{4}\right)$-treated pigs; $n=3$ for OVX + progesterone + OB-treated pigs. The means of two replicates per animal were used.

and resuspended in the same buffer $(50 \mu \mathrm{l})$ supplemented with $0.05 \mu \mathrm{g} \mathrm{PKI}, 10 \mu \mathrm{Ci}\left[\gamma^{32} \mathrm{P}\right]$-ATP and $20 \mu \mathrm{g} \mathrm{MBP}$ as a substrate. The reactions were conducted for $30 \mathrm{~min}$ at $30^{\circ} \mathrm{C}$. Preliminary experiments showed that under these conditions, the incorporation of ${ }^{32} \mathrm{P}$ into MBP is linear and proportional to the amount of oviductal proteins $(100 \mu \mathrm{g})$ used (Fig. 1a). The reaction was terminated by adding $25 \mu$ l doublestrength SDS sample buffer (125 mmol Tris $\mathrm{I}^{-1}(\mathrm{pH} 6.8), 4 \%$ 
(w/v) glycerol, $10 \%$ (v/v) $\beta$-mercaptoethanol) and boiling for 5 min to determine MAP $^{42 k}$ activity. MBP was resolved by $12 \%(\mathrm{w} / \mathrm{v})$ SDS-PAGE followed by autoradiography and quantified by excising the MBP from the dried gel and determining associated radioactivity. The labelling of $\mathrm{MBP}$ of the four ovariectomized pigs was expressed as 100\% MAP kinase activity and was used as the base for comparison of the effects of hormone treatment.

\section{Cell cycle analysis}

Cell cycle analysis was performed as described by Löhrke et al. (1998). The oviductal tissue (ampullaryisthmic junction) was minced and digested at $37^{\circ} \mathrm{C}$ with $10 \mathrm{ml}$ of $0.1 \%(\mathrm{w} / \mathrm{v})$ collagenase. The digestion was repeated and the cells were filtered through a $30 \mu \mathrm{m}$ gauze. The filtrate was spun off (200 $\mathrm{g}$ for $10 \mathrm{~min})$, washed by RPMI-HBS and the erythrocytes were lysed by resuspending the cells in water. After centrifugation at $250 \mathrm{~g}$ for $10 \mathrm{~min}$, the cells were resuspended in RPMI-HBS and the viability of cells was estimated by propidium iodide staining. The proportion of intact oviductal cells was $76-81 \%$, which consisted of $70 \%$ epithelial cells (cytokeratin positive) and $4 \%$ stromal cells (vimentin positive) as detected by immunofluorescence staining with a flow cytometer (Coulter, Elite). Cell density was determined by cell counter. Aliquots $\left(10^{6}\right.$ cells $\left.\mathrm{ml}^{-1}\right)$ were fixed in $70 \%(\mathrm{v} / \mathrm{v})$ ethanol, washed and treated with RNase A $\left(1 \mathrm{mg} \mathrm{ml}^{-1}\right.$ in PBS at $37^{\circ} \mathrm{C}$ for $30 \mathrm{~min}$ ) after denaturation of DNases by heating the RNase A solution at $85^{\circ} \mathrm{C}$ for 60 min (Stöhr et al., 1978). After incubation for $30 \mathrm{~min}$ with propidium iodide $(70 \mu \mathrm{mol}$ $\mathrm{I}^{-1}$ ) in $5 \mathrm{mmol}$ Hepes $\mathrm{I}^{-1}, \mathrm{pH} 7.3$, in $150 \mathrm{mmol} \mathrm{NaCl}{ }^{-1}$, flow cytometry was performed and the cell cycle was analysed by a computer-aided Multicycle Program (Phoenix, San Diego, CA).

\section{Distribution of $m R N A$}

Oviductal tissue (1 g) was homogenized with a Dounce homogenizer (Wheaton) in $2 \mathrm{ml}$ hypotonic buffer containing $5 \mathrm{mmol} \mathrm{MgCl}_{2} \mathrm{I}^{-1}$. Nuclei were centrifuged at $700 \mathrm{~g}$ for $10 \mathrm{~min}$ to prepare the postmitochondrial supernatant. The cytoplasmic extract was centrifuged at $30000 \mathrm{~g}$ for $20 \mathrm{~min}$ and the resulting postmitochondrial supernatant was layered on $15-45 \% \quad(w / w)$ sucrose gradients and centrifuged at $24000 \mathrm{~g}$ for $16 \mathrm{~h}$ at $4^{\circ} \mathrm{C}$. The gradients were fractionated and fractions containing polysomal- $(>80 \mathrm{~S})$ and free mRNA $(<40 \mathrm{~S})$ were detected by ${ }^{3}[\mathrm{H}]$-poly $(U)$-hybridization. Poly $(U)$-hybridization was performed according to Lee and Engelhardt (1979).

\section{Explant culture}

Individual oviducts (ampullary-isthmic junction) dissected with scissors were collected into ice-cold HBSS (Hank's balanced salt solution). Pieces were minced and dried using filter paper. Tissue portions (0.2 g) were weighed, cut into
Table 2. Results of ANOVA

\begin{tabular}{lcr}
\hline Variable measured & Fvalue & $P$ value \\
\hline Kinase assay & 14.1 & 0.0025 \\
Cell cycle analysis & 25.3 & $<0.0001$ \\
Distribution of polysomal and free mRNA & 6.27 & 0.0058 \\
Mean density & 5.6 & 0.0128 \\
\hline
\end{tabular}

small pieces and transferred to a Petri dish $(35 \mathrm{~mm})$ with $2 \mathrm{ml}$ incubation medium (phenol red-free RPMI 1640 medium containing $0.25 \% \quad(\mathrm{w} / \mathrm{v}) \quad \mathrm{BSA}, \quad 1 \% \quad(\mathrm{v} / \mathrm{v})$ antibiotic-antimycotic (ABAM) and 2 mmol L-glutamine $\mathrm{I}^{-1}$ ) on a rocker platform at $37^{\circ} \mathrm{C}$ under $\mathrm{O}_{2}: \mathrm{N}_{2}: \mathrm{CO}_{2}(50: 45: 5)$. After $60 \mathrm{~min}$ of culture, the medium was replaced with incubation medium containing different concen-

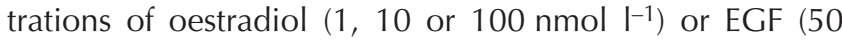
or $100 \mathrm{nmol}^{-1}$ ). Explants were harvested $24 \mathrm{~h}$ after incubation. The explants were rinsed twice with ice-cold HBSS, dried with filter paper and stored at $-80^{\circ} \mathrm{C}$ until required. Explants of ovariectomized pigs were used for these studies to minimize the effects of endogenous steroid hormones. Preliminary experiments demonstrated that a culture time of $24 \mathrm{~h}$ was required to detect a tissue reaction to oestradiol and EGF.

\section{Statistical analysis}

The data are mean \pm SD. All data were analysed by oneway ANOVA (SigmaStat, version 1.0) with a fixed factor treatment $(\mathrm{OVX}, \mathrm{OVX}+\mathrm{OB}, \mathrm{OVX}+$ progesterone, OVX + progesterone $+\mathrm{OB}$, day 12 , day 20 ) for chosen time points performed separately.

Model: $y_{\mathrm{ij}}=\mu+T_{\mathrm{i}}+e_{\mathrm{ij}}$ in which $y_{\mathrm{ij}}=$ measurements, $\mu=$ overall mean, $T_{\mathrm{i}}={ }^{\prime} \mathrm{i}$ '-th level of factor treatment ( $\mathrm{i}=1, . .6)$ and $e_{\mathrm{ij}}=$ random error. If the main treatment effects were significant, the post-hoc tests $(t$ test, $P<0.05$ ) were performed in the following way: (i) steroid hormone analysis (Fig. 2): between treatments comparisons were done for day 1 or day 9 after ovariectomy or day 19 of the oestrous cycle. Within treatments, paired $t$ tests were performed between day 11 and day 19 of the oestrous cycle or between day 1 and day 9 after ovariectomy. (ii) Kinase assay (Fig. 1): for this analysis the results of the control treatment OVX were set at $100 \%$ and the results of all other treatments were calculated relative to OVX and the same model as mentioned above was used. (iii) Cell cycle analysis and distribution of polysomal and free mRNA (Figs 3 and 4): between treatment comparisons were done for days 12,20 and 10 after ovariectomy. The $F$ and $P$ values of ANOVA are shown (Table 2). For evaluation of the immunoblots the absorbance of the bands from the scanned films was analysed by one-Dscan software (Scanalytics, Fairfax, VA) and calculated as mentioned above. 

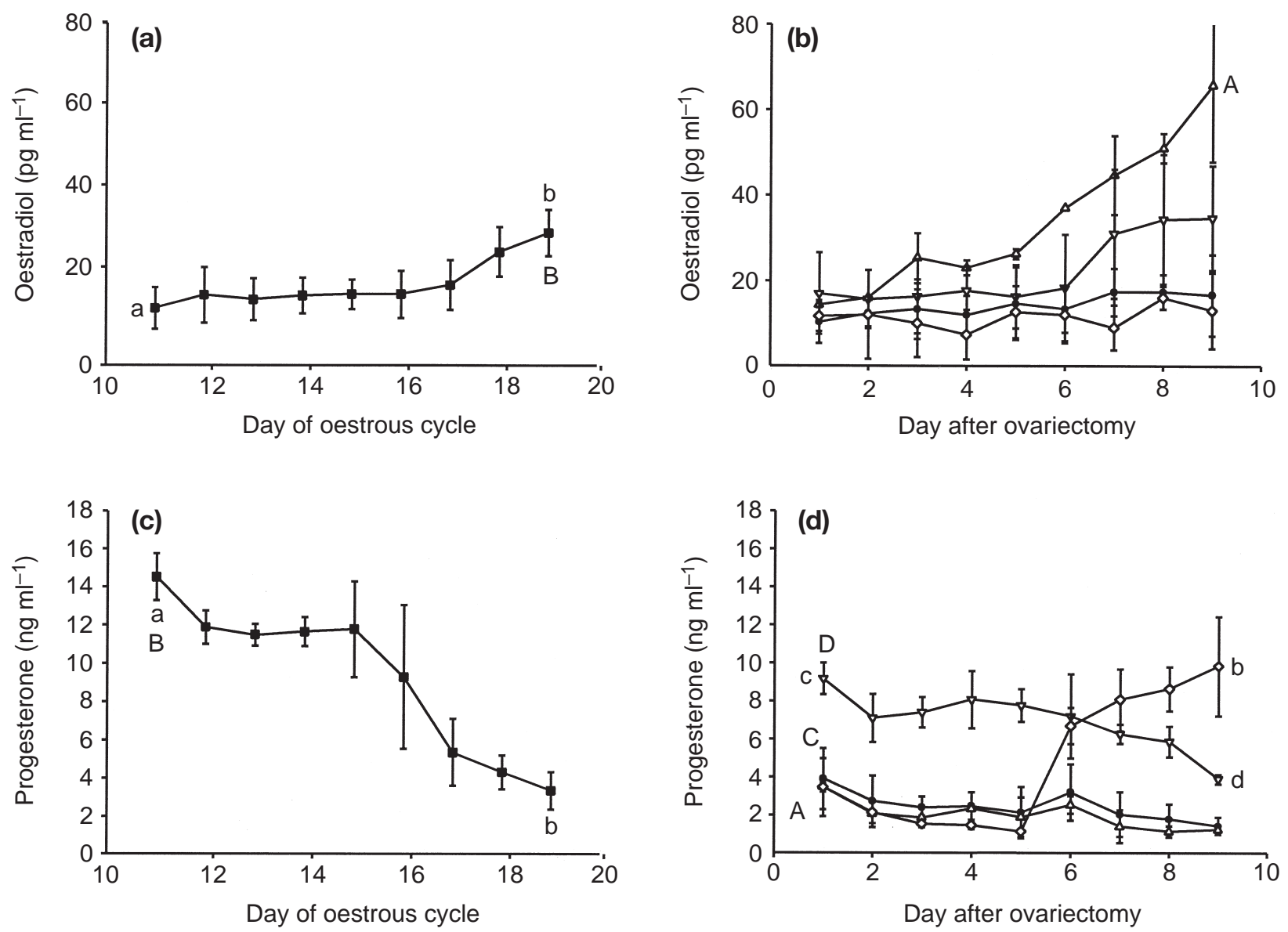

Fig. 2. Plasma concentrations of $(\mathrm{a}, \mathrm{b})$ oestradiol and $(\mathrm{c}, \mathrm{d})$ progesterone in cyclic pigs. $\square$ : Day 20 group $(n=5)$; O: ovariectomized pigs $(n=4)$; $\triangle$ : ovariectomized pigs that received oestradiol benzoate $(n=4)$; $\diamond$ : ovariectomized pigs treated with progesterone $(n=3) ; \nabla$ : ovariectomized pigs injected with progesterone and oestradiol benzoate $(n=3)$. ab or ${ }^{\mathrm{cd}}$ values in the same line plot and $\mathrm{AB}$ or $\mathrm{CD}$ values between the different line plots are significantly different $(P<0.05)$. Plasma steroid concentrations were detected at 14:00 $\mathrm{h}$ and steroid treatment of pigs took place at 08:00 $\mathrm{h}$ on the same day.

\section{Results}

\section{Plasma concentrations of oestradiol and progesterone}

In cyclic pigs there was an increase in mean oestradiol concentrations in plasma from day 11 to day 19 of the oestrous cycle $\left(12.0 \pm 5.6\right.$ and $26.6 \pm 5.8 \mathrm{pg} \mathrm{ml}^{-1}$, respectively; $P<0.05)$. Treatment of ovariectomized gilts with oestradiol benzoate for 4 days produced plasma oestradiol concentrations of $65.7 \pm 17.9 \mathrm{pg} \mathrm{ml}^{-1}$ compared with $26.6 \pm 5.8 \mathrm{pg} \mathrm{m}^{-1}$ on day 19 of the oestrous cycle $(P<0.05)$. Application of oestradiol benzoate to ovariectomized gilts after pretreatment with progesterone for 5 days resulted in an increase in the plasma oestradiol concentrations on day 9 after ovariectomy compared with the values of cyclic animals on day 19 (34.7 $\pm 12.2 \mathrm{pg} \mathrm{ml}^{-1}$ and $26.6 \pm 5.8 \mathrm{pg} \mathrm{ml}^{-1}$, respectively; not significant; Fig. 2a,b).

Plasma progesterone concentration decreased from day $11\left(14.5 \pm 1.2 \mathrm{ng} \mathrm{ml}^{-1}\right)$ to day $19\left(3.3 \pm 0.9 \mathrm{ng} \mathrm{ml}^{-1}\right.$; $P<0.05)$ of the oestrous cycle. Plasma progesterone concentrations at 1 day after ovariectomy in gilts were comparable to values of cyclic animals on day $11(P<0.05)$ and remained at 1.0-2.0 ng ml-1 after oestradiol benzoate administration. Progesterone treatment of pigs from day 6 to day 9 after ovariectomy increased the plasma progesterone concentrations $(P<0.05)$. In ovariectomized gilts that received oestradiol benzoate after a pretreatment with progesterone, the plasma progesterone concentration on day 1 after ovariectomy was higher than in the ovariectomized group $\left(9.2 \pm 0.8\right.$ and $3.9 \pm 1.6 \mathrm{ng} \mathrm{ml}^{-1}$, respectively; $P<0.05)$ and finally decreased on day 9 $(P<0.05)$ (Fig. 2c,d).

\section{MAP42k abundance and activity}

The abundance of MAP42k in oviductal tissue appears to be independent of the endogenous plasma steroid hormone concentrations of the pigs, as determined by immunoblotting with the corresponding antibody (Fig. 5). 


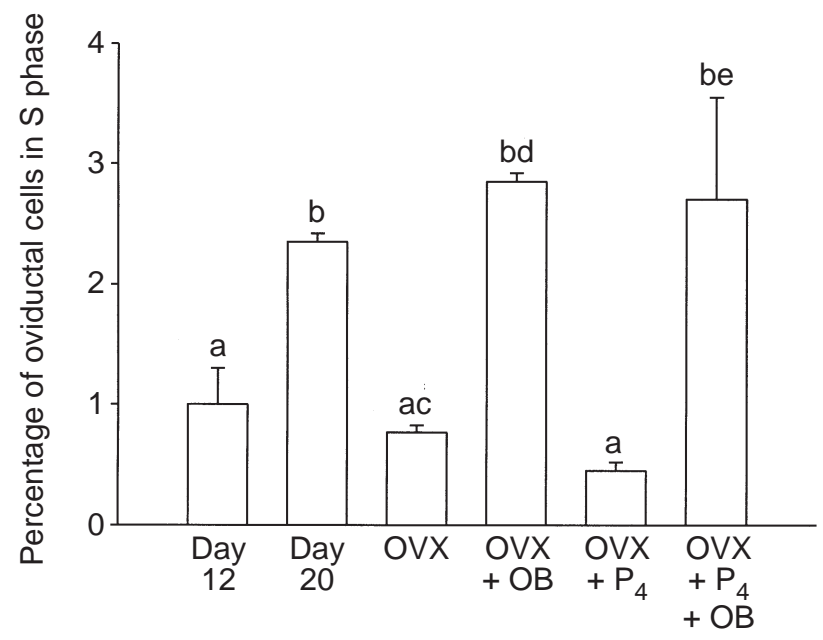

Fig. 3. Percentage of oviductal cells in $S$ phase in cyclic and steroid-treated pigs. Three animals of each treatment group (day 12, day 20, ovariectomized $(\mathrm{OVX}), \mathrm{OVX}+$ oestradiol benzoate $(\mathrm{OB}), \mathrm{OVX}+$ progesterone $\left.\left(\mathrm{P}_{4}\right), \mathrm{OVX}+\mathrm{P}_{4}+\mathrm{OB}\right)$ were used in independent experiments. The means of two replicates per animal were used. ${ }^{a-e}$ Values with different letters are significantly different $(P<0.05)$.

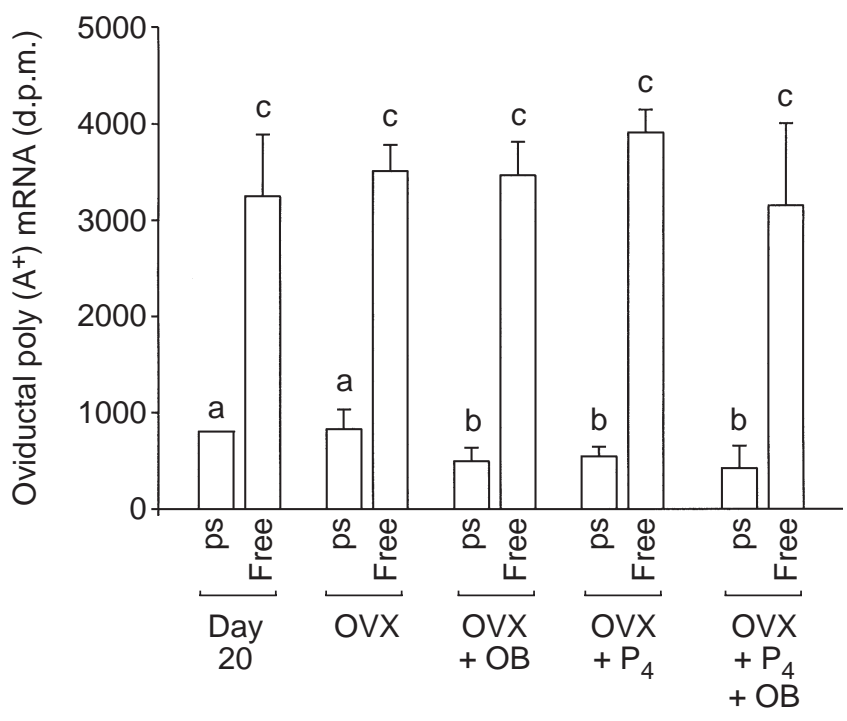

Fig. 4. Distribution of polysomal (ps; $>80 \mathrm{~S})$ and free $(<40 \mathrm{~S})$ mRNA in oviductal tissue of cyclic pigs and after steroid replacement therapy of ovariectomized (OVX) gilts. Three (day 20, OVX, OVX + oestradiol benzoate $\left.(\mathrm{OB}), \mathrm{OVX}+\mathrm{P}_{4}+\mathrm{OB}\right)$ or two $\left(\mathrm{OVX}+\mathrm{P}_{4}\right)$ pigs of each treatment group were used in independent experiments. abc Values with different letters are significantly different $(P<0.05)$.

The immune complex kinase assay showed that MAP42k activity was stimulated $(P<0.05)$ in oviductal tissue after ovariectomy plus oestradiol treatment or ovariectomy plus progesterone + oestradiol benzoate treatment compared with the activity in the tissue of ovariectomized pigs. Furthermore, the phosphorylation of MBP was higher in cyclic day 20 gilts compared with day 12 pigs (Fig. 1b,c). Progesterone appears to decrease $\mathrm{MAP}^{42 \mathrm{k}}$ activity. Consistent with the results from the kinase assay, the immune signals for the activated MAP kinase (MAP42k, Tyrphosphorylated) were stronger in oviductal preparations collected after ovariectomy plus oestradiol treatment or ovariectomy plus progesterone plus oestradiol benzoate treatment compared with the signals of ovariectomized animals (Fig. 1c,d).

Tyr-phosphorylation of MAP42k was upregulated in oviductal explants from ovariectomized pigs cultured with

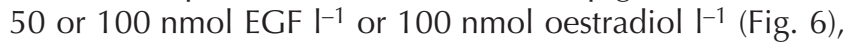
but the immune complex kinase assay of these explants showed no significant differences (data not shown).

\section{E-BP1 phosphorylation}

The 4E-BP1 appeared as a single band of molecular mass of approximately $18 \mathrm{kDa}$ (Fig. 7a) when extracted from the oviduct of ovariectomized pigs and subjected to $15 \%(\mathrm{w} / \mathrm{v})$ SDS-PAGE. Inactivation of 4E-BP1 by multiple phosphorylations resulted in several phosphorylated forms with decreased electrophoretic mobility (von Manteuffel et al., 1996). Treatment of ovariectomized gilts with oestradiol benzoate or progesterone plus oestradiol benzoate led to reduced mobility of 4E-BP1 on gels, which is indicative of both phosphorylation and inactivation. A comparable band pattern of the binding protein was observed in oviductal pig tissue on day 20 of the oestrous cycle. Progesterone treatment of ovariectomized pigs did not result in a reduction of the $4 \mathrm{E}-\mathrm{BP} 1$ on gels and the 4E-BP1 was not phosphorylated in oviductal tissue from the mid-phase of the ovarian cycle. EGF and oestradiol treatment of oviductal explants from ovariectomized pigs led to reduced mobility of 4E-BP1 on gels (Fig. 7b and Table 3).

\section{Cell cycle}

The percentage of oviductal cells in the DNA synthesis (S) phase of the cell cycle in cyclic gilts and after steroid replacement therapy in ovariectomized gilts is shown (Fig. 3). DNA synthesis was relatively lower in oviductal cells from ovariectomized pigs. Oestradiol benzoate treatment of ovariectomized pigs promoted the cell cycle activity of these cells $(P<0.05)$, demonstrating a marked increase in the percentage in cellular $S$ phase. Progesterone did not stimulate the rate of DNA synthesis. Administration of oestradiol benzoate to ovariectomized gilts after pretreatment with progesterone for 5 days resulted in stimulation of cell cycle activity $(P<0.05)$. The plasma steroid hormone concentrations in these pigs were comparable to the corresponding plasma hormone concentrations of cyclic gilts in the preovulation period of the ovarian cycle. In both groups, the proportion of cells showing DNA synthesis was in a similar range. The stimulating effect of oestradiol on the cell cycle activity is 
Table 3. Evaluation of eukaryotic initiation factor 4E (4E-BP1) band shift after culture of ovariectomized explants with oestradiol and epidermal growth factor (EGF)

\begin{tabular}{|c|c|c|c|}
\hline Treatment & Band & Relative migration (\%) & Intensity of absorbance (\%) \\
\hline \multirow[t]{2}{*}{ Vehicle } & 1 & 33.3 & 100 \\
\hline & 2 & nd & nd \\
\hline \multirow[t]{2}{*}{$1 \mathrm{nmol}$ oestradiol $\mathrm{I}^{-1}$} & 1 & 35.7 & 100 \\
\hline & 2 & nd & nd \\
\hline \multirow[t]{2}{*}{10 nmol oestradiol $\mathrm{I}^{-1}$} & 1 & 35.7 & 51 \\
\hline & 2 & 29.5 & 49 \\
\hline \multirow[t]{2}{*}{100 nmol oestradiol $\mathrm{I}^{-1}$} & 1 & 35.4 & 31 \\
\hline & 2 & 30.0 & 69 \\
\hline \multirow[t]{2}{*}{$50 \mathrm{nmol} \mathrm{EGF}^{-1}$} & 1 & 36.2 & 30.3 \\
\hline & 2 & 29.2 & 69.7 \\
\hline \multirow[t]{2}{*}{$100 \mathrm{nmol} \mathrm{EGF} \mathrm{I}^{-1}$} & 1 & 33.6 & 40.1 \\
\hline & 2 & 28.2 & 59.9 \\
\hline
\end{tabular}

nd: not detected.

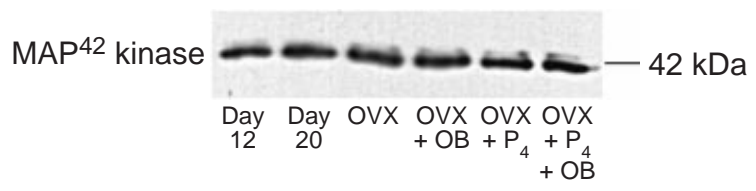

Fig. 5. Immunoblot analysis of mitogen-activated protein kinase (MAP ${ }^{42}$ kinase) in oviductal tissue of cyclic and steroid-treated pigs after $9 \%(\mathrm{w} / \mathrm{v})$ PAGE. The data presented are representative of these experiments. The experiments were repeated with different animals: $n=3$ for day $12 ; n=5$ for day $20 ; n=4$ for ovariectomized (OVX); $n=4$ for OVX + oestradiol benzoate (OB); $n=3$ for OVX + progesterone $\left(\mathrm{P}_{4}\right)$; and $n=3$ for $\mathrm{OVX}+\mathrm{P}_{4}+\mathrm{OB}$.

also supported by an increased percentage of cells in $\mathrm{S}$ phase in day 20 pigs compared with day 12 pigs with lower endogenous plasma oestradiol concentrations $(P<0.05)$.

\section{Distribution of $m R N A$}

The distribution of polysomal (> $80 \mathrm{~S})$ and free $(<40 \mathrm{~S})$ mRNA in oviductal tissue of cyclic pigs and after steroid replacement therapy in ovariectomized gilts is shown (Fig. 4). In all the treatment groups investigated, there were no significant differences in the distribution of free oviductal poly $\left(\mathrm{A}^{+}\right) \mathrm{mRNA}$. Treatment of ovariectomized pigs with oestradiol or progesterone resulted in a significant decrease $(P<0.05)$ in polysomal mRNA concentrations compared with ovariectomized pigs.

\section{Discussion}

Many steps of EGF receptor signal transduction have been determined using carcinoma cell lines. However, to our knowledge, data on the molecular and biochemical mechanisms that direct EGF receptor system-mediated

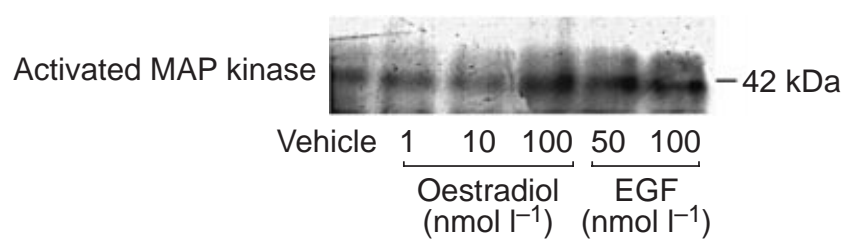

Fig. 6. Immunoblot analysis of activated mitogen-activated protein kinase (MAP42 kinase) after culture of oviductal tissue of ovariectomized (OVX) pigs for $24 \mathrm{~h}$ with different concentrations of oestradiol and epidermal growth factor (EGF). A typical immunoblot of these experiments is shown. The tissue of three OVX pigs was cultured in independent experiments and the abundance of activated MAP kinase was analysed.

processes of proliferation and differentiation in oviductal cells that undergo synchronized waves of oestrogen and progesterone flux have not been reported. Therefore, the first aim of the present study was to determine whether oestrogen and progesterone influence the abundance and bioactivity of EGF-regulated specific markers of transcription and translation in pig oviducts during the oestrous cycle and after steroid replacement therapy. A second aim was to characterize the direct involvement of EGF in the expression and bioactivation of these factors in reproductive tissue.

The results of the present study demonstrate that the abundance of $\mathrm{MAP}^{42 \mathrm{k}}$ in oviductal tissue is apparently independent of the maternal plasma steroid hormone concentrations. However, the MAP42k activity, which requires the phosphorylation of both threonine and tyrosine residues (Boulton et al., 1991), appears to be stimulated by oestradiol, as demonstrated by increased phosphorylation of MBP in oestradiol benzoate- and progesterone plus oestradiol benzoate-treated ovariectomized pigs compared with the phosphorylation rate in ovariectomized pigs. Furthermore, the phosphorylation of this protein was higher 
(a)

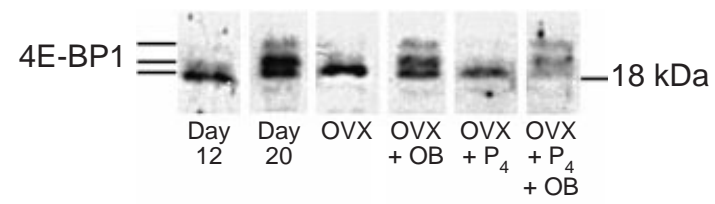

(b)

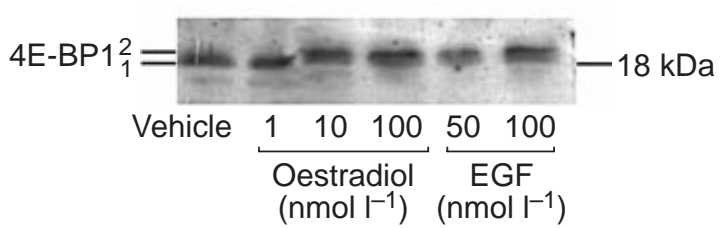

Fig. 7. (a) Mobility of eukaryotic initiation factor 4E (4E-BP1) from oviductal tissue of cyclic and steroid-treated gilts on polyacrylamide gels, demonstrated by immunoblotting after PAGE. (b) Determination of 4E-BP1 band shift in oviductal tissue of ovariectomized (OVX) pigs depending on oestradiol and epidermal growth factor (EGF) treatment. The following numbers of animals were used in independent experiments: (a): $n=4$ (day 20, OVX, OVX + oestradiol benzoate $(\mathrm{OB})$ ) or $n=3$ (day 12, OVX + progesterone $\left.\left(\mathrm{P}_{4}\right), \mathrm{OVX}+\mathrm{P}_{4}+\mathrm{OB}\right)$; (b): the tissue of two OVX pigs was cultured and analysed (aliquots from each tissue were assayed by electrophoresis in duplicate). Typical immunoblots of these experiments are shown.

in pigs on day 20 compared with pigs on day 12 . It is possible that progesterone may have decreased MAP42k activity, although additional data are required to support this observation. MAP kinases are found in both the nucleus and the cytoplasm, and MAP kinases may function at the distal end of a ras-dependent signalling pathway, transducing receptor-initiated signals to the nucleus (Satoh et al., 1990; Wood et al., 1992). The activation of the MAP kinases is thought to stimulate gene expression and cell division in the oviductal tissue, because a number of transcription factors such as c-Jun and c-Myc are substrates for these kinases. This contention is supported by a high oviductal cell cycle activity in pigs with high plasma oestradiol concentrations, as demonstrated by a pronounced increase in the percentage of cells in S-phase. Furthermore, results from Swantek and Baserga (1999) indicate that the duration of MAP kinase activation is crucial for determining cellular responses (whether a cell will differentiate or proliferate).

The results of the present study also indicate that the cellular translation rates in oviductal tissue are modulated in response to ovarian steroids. This control appears to be cap-dependent as indicated by our data concerning $4 \mathrm{E}-$ BP1 inactivation. The phosphorylation of 4E-BP1 in the oviductal tissue of pigs appears to be dependent on oestradiol, as treatment of ovariectomized gilts with oestradiol benzoate or progesterone plus oestradiol benzoate led to reduced mobility of 4E-BP1 on gels. This finding is supported by observation of several bands of $4 \mathrm{E}-$ BP1 of approximately $20 \mathrm{kDa}$ in cytosolic preparations of day 20 pigs compared with day 12 animals. The phosphorylation of $4 \mathrm{E}-\mathrm{BP} 1$ reduces the ability of the protein to interact with elF-4E, which results in the enhancement of translation initiation of mRNAs with extensive secondary structure (Pause et al., 1994).

However, a significant increase of polysomal poly $\left(\mathrm{A}^{+}\right)$ mRNA in oviductal tissues collected from gilts with high endogenous plasma oestradiol concentrations could not be detected by the separation of polysomal and free mRNA by gradient centrifugation. Instead, a decrease in polysomal poly $\left(\mathrm{A}^{+}\right) \mathrm{mRNA}$ was observed after mitogenic stimulation, showing that $4 \mathrm{E}-\mathrm{BP} 1$ phosphorylation is only one of the factors required for regulation of cellular protein translation. However, the possibility that the translation rate of specific mRNAs increases in these cells could not be excluded. Measurement of overall protein synthesis and an in vitro translation test should resolve whether this contention is correct.

The stimulating effect of oestradiol on the MAP kinase and 4E-BP1 activity might be mediated by the EGF receptor system, as higher concentrations of this receptor were found in oviductal tissue under oestrogen dominance (Wollenhaupt et al., 1997, 2001). This contention is supported the observation that both the tyrosine phosphorylation of MAP42k and the gel mobility retardation of $4 \mathrm{E}-\mathrm{BP} 1$ are also stimulated by oestradiol and EGF in cultured oviductal explants of ovariectomized pigs. Wollenhaupt et al. (2001) demonstrated that the EGF receptor tyrosine kinase could also be activated in the oviduct of ovariectomized pigs.

In conclusion, the results of the present study indicate that the bioactivity of specific markers of transcription and translation such as MAP42k and 4E-BP1 in pig oviducts is dependent on maternal plasma steroid hormone concentrations. These findings are supported by an increase in oviductal cell cycle activity of pigs with high plasma oestradiol concentrations. The stimulation of EGF receptor mRNA and protein concentration by oestradiol benzoate (Wollenhaupt et al., 2001), and the stimulating effect of oestradiol and EGF on gel mobility retardation of the 4EBP1 in cultured oviductal explants of ovariectomized pigs, indicate that EGF may mediate the effect of oestradiol in the oviduct. Therefore, the mitogenic effect of oestradiol in the proliferative phase of the oestrous cycle may be regulated by the EGF receptor system, resulting in an oviductal metabolism that is able to support the viability of early embryos.

The authors would like to thank P. Huff for his English review. This work was supported by a grant from the Deutsche Forschungsgemeinschaft (DFG Wo 663/2-1).

\section{References}

Ahn NG, Weiel JE, Chan CP and Krebs EG (1990) Identification of multiple epidermal growth factor-stimulated protein serine/threonine kinases from swiss 3T3 cells Journal of Biological Chemistry 26511 487-11 494

Ballou LM, Luther H and Thomas G (1991) MAP42 kinase and 70k S6 kinase lie on distinct signalling pathways Nature $\mathbf{3 4 9} 348-350$ 
Blödow G, Götze M, Kitzig M, Brüssow KP and Duschinski U (1988) Radioimmunologische Steroidbestimmungen in der Follikelflüssigkeit bei Rind und Schwein Isotopenpraxis 24 151-155

Boulton TG, Nye SH, Robbins DJ et al. (1991) ERKs: a family of proteinserine/threonine kinases that are activated and tyrosine phosphorylated in response to insulin and NGF Cel/ 65 663-675

Brown EJ, Albers MA, Shin TB, Ichikawa K, Keith CT, Lane WS and Schreiber SL (1994) A mammalian protein targeted by G1-arresting rapamycin-receptor complex Nature 369 756-758

Chegini N, Rossi MJ and Masterson BJ (1992) Platelet derived growth factor (PDGF), epidermal growth factor (EGF), EGF and PDGF $\beta$ receptors in human endometrial tissue: localisation and in vitro action Endocrinology 130 2373-2385

Garach-Jehoshua O, Ravid A, Liberman UA and Koren H (1999) 1,25Dihydroxyvitamin $\mathrm{D}_{2}$ increases the growth promoting activity of autocrine epidermal growth factor receptor ligands in keratinocytes Endocinology $140713-721$

Hammond MG, Oh S-T, Anners J, Surrey ES and Halme J (1993) The effect of growth factors on the proliferation of endometrial cells in culture American Journal of Obstetrics and Gynecology 168 1131-1138

Huet-Hudson YM, Chakraborty C, De SK, Suzuki Y, Andrews GK and Dey SK (1990) Oestrogen regulates the synthesis of epidermal growth factor in mouse uterine epithelial cells Molecular Endocrinology 4 510-523

Jansen RPS (1980) Cyclic changes in the human Fallopian tube isthmus and their functional importance American Journal of Obstetrics and Gynecology 136 292-308

Lee SL and Engelhardt DL (1979) Peptide coding capacity of polysomal and non-polysomal messenger RNA during growth of animal cells Journal of Molecular Biology 126 221-233

Löhrke B, Viergutz T, Shahi SK, Pöhland R, Wollenhaupt K, Goldammer T, Walzel H and Kanitz W (1998) Detection and functional characterization of the transcription factor peroxisome proliferatoractivated receptor $\gamma$ in lutein cells Journal of Endocrinology 159 429-439

Lowry OH, Rosebrough NJ, Farr AL and Randall RJ (1951) Protein measurement with the folin phenol reagent Journal of Biological Chemistry 193 265-275

Marcus G (1974) Mitosis in the rat uterus during the oestrus cycle, early pregnancy, and early pseudopregnancy Biology of Reproduction 10 447-452

Mukku VR and Stancel GM (1985) Regulation of epidermal growth factor receptor by oestrogen Journal of Biological Chemistry $\mathbf{2 6 0}$ 9820-9824
Pause A, Belshem GJ, Gingras A-C, Donze O, Lin T-A, Lawrence JR and Sonenberg $\mathbf{N}$ (1994) Insulin-dependent stimulation of protein synthesis by phosphorylation of a regulator of $5^{\prime}$-cap function Nature 371 762-767

Salvatori L, Ravenna L, Felli MP, Cardillo MR, Russo MA, Frati L, Gulino A and Petrangeli E (2000) Identification of an oestrogen-mediated deoxyribonucleic acid-binding independent transactivation pathway on the epidermal growth factor receptor gene promotor Endocrinology 141 2266-2274

Satoh T, Nakafuku M and Kaziro Y (1990) Function of Ras as a molecular switch in signal transduction Journal of Biological Chemistry 267 24 149-24 152

Stöhr M, Vogt-Schaden M, Knobloch M and Vogel R (1978) Evaluation of eight fluorochrome combinations for simultaneous DNA-protein flow analysis Stain Technology 53 205-215

Swantek JL and Baserga G (1999) Prolonged activation of ERK2 by epidermal growth factor and other growth factors requires a functional insulin-like growth factor 1 receptor Endocrinology $1403163-3169$

von Manteuffel SR, Gingras A-C, Ming X-F, Sonenberg N and Thomas G (1996) 4-EBP1 phosphorylation is mediated by FRAP-p70s6k pathway and is independent of mitogen-activated protein kinase Proceedings National Academy of Sciences USA 93 4076-4080

Watson H, Franks S and Bonney RC (1996) Regulation of epidermal growth factor receptor synthesis by ovarian steroids in human endometrial cells in culture Journal of Reproduction and Fertility 107 199-205

Wollenhaupt K, Tiemann U, Einspanier R, Schneider F, Kanitz W and Brüssow KP (1997) Characterization of the epidermal growth factor receptor in pig oviduct and endometrium Journal of Reproduction and Fertility 111 173-181

Wollenhaupt K, Kettler A, Brüssow K-P, Schneider F, Kanitz W and Einspanier R (2001) Regulation of the expression and bioactivation of the epidermal growth factor receptor system by estradiol in pig oviduct and endometrium Reproduction, Fertility and Development 13 161-176

Wood KW, Sarnecki C, Roberts TM and Blenis J (1992) Ras-mediated nerve factor receptor modulation of three signal-transducing protein kinases: MAP kinase, Raf-1, and RSK Cell 68 1041-1050

Received 12 April 2001

First decision 2 July 2001

Accepted 17 August 2001. 